Newfoundland and Labrador Studies

\title{
Memorial University's First Sociologist: The Dilemmas of a Bureaucratic Intellectual
}

\section{Stephen Harold Riggins}

Volume 29, Number 1, Spring 2014

URI: https://id.erudit.org/iderudit/1062245ar

DOI: https://doi.org/10.7202/1062245ar

See table of contents

Publisher(s)

Faculty of Arts, Memorial University

ISSN

$1719-1726$ (print)

$1715-1430$ (digital)

Explore this journal

Cite this article

Riggins, S. (2014). Memorial University's First Sociologist: The Dilemmas of a Bureaucratic Intellectual. Newfoundland and Labrador Studies, 29(1).

https://doi.org/10.7202/1062245ar viewed online.

https://apropos.erudit.org/en/users/policy-on-use/ 


\title{
Memorial University's First Sociologist: The Dilemmas of a Bureaucratic Intellectual
}

\author{
STEPHEN HAROLD RIGGINS
}

\section{INTRODUCTION}

Memorial University's first sociologist, Donald Willmott, was cross-appointed to the provincial government's Department of Public Welfare and the university. In addition to introducing undergraduates to the discipline of sociology he was expected to work as a part-time researcher and adviser for Public Welfare. His main dilemma as a bureaucratic intellectual was choosing between the role of a fact-finder, who tended to substantiate Welfare officials' perceptions of reality, and the role of a policy adviser, who defined the job in a more ambitious manner and took the initiative of offering uninvited remedies along with "the facts." The first option was consistent with a satisfying university career. The second option could potentially lead to a more insecure career because the role of a policy adviser at Public Welfare was not institutionalized in a manner that encouraged serious thinking about policy. The experiences of Donald Willmott and his wife Elizabeth tell us about the nature of faculty appointments that blur the distinction between discipline research and policy research; about the way liberal Americans reacted to Newfoundland society in the 1950s; and about academic mores at Memorial University, especially the lingering influence of religion at a secular university. Before discussing Donald Willmott's years in Newfoundland, it is essential to review his family's involvement in the social gospel movement, his childhood in China, and his American education in sociology. These experiences shaped his outlook on life and his approach to sociology. 


\section{Riggins}

Born in 1925 in Renshou, Sichuan, China, Willmott arrived at Memorial University in 1956 to teach at the old Parade Street campus. One of the referees described him as an "easy-going, likeable individual who is supported at home by a very friendly and outgoing young woman." When they arrived in St. John's, the Willmotts had one son, Kenneth, who celebrated his second birthday in September 1956. The next year Elizabeth gave birth to their daughter Carol. The following remarks from an interview in the summer of 2013 show how engaging Donald Willmott could be - even at the age of 88 - when he talked about Chinese politics from the era of his youth, the 1930s and 1940s:

I guess it was because dad was so immersed in Chinese politics that I was constantly meeting people like one of the warlords who came to visit dad. I got his best wishes in my autograph book. I was very much in touch with current affairs in China. I was an active participant in a missionary discussion group that varied from 15 to 30 people and met every month. In my second year of high school I set up a table of left-wing books. I put up a poster which I changed from time to time. On one poster I traced a picture of Lenin. Dad joined a book club called the Left Book Club. I was an avid reader of the books distributed by the Left Book Club. Dad and the rest of us were radicalized before we knew much about the Chinese Communists, believe it or not. The Left Book Club was sympathetic to the Soviet Union. All of us thought the Soviet Union was the way to go - not realizing the true nature of Lenin and Stalin. From high school days I was a propagandist and promoter of leftism. (Willmott, 2013)

Without the family's involvement in the social gospel, Donald probably would not have become a sociologist. The social gospel emphasized the obligation of Christians to combat social inequality and to some extent it secularized the faith. Although the social gospel inspired the first generation of Canadian sociologists, those who obtained academic positions between the 1890s and the early 1920s, it is unusual for the movement to have a strong influence on Canadian sociologists of Willmott's age. Donald Willmott's great-grandparents, J.B. (James Branston) Willmott and his wife, were prominent figures in Toronto Methodism. ${ }^{2}$ Walter Willmott, Donald's grandfather, was also active in the Methodist Church, holding several lay offices (anon., 1941). But the most intimate link with the social gospel was through Donald's grandmother, Margaret (Thom) Willmott. "My grandparents were rather distant from each other," Donald 
says. His grandmother had what he calls "an obsession or a crush" on Rev. Salem Bland, one of the leaders of the social gospel in Canada. Donald has no precise knowledge of his grandfather's religious beliefs but says that Walter dismissed Salem Bland as "that white-haired boy." The shorthand label Donald Willmott used to describe his grandmother and father's religious outlook is Christian socialism. "Dad always considered himself a socialist in Canada. The Communist Party in Canada did not appeal to him, but after 1938 in China he was an underground communist" (Willmott, 2013).

\section{“CHINA IS ALWAYS WITH ME"}

After serving in World War I, Donald's father, L. (Leslie) Earl Willmott (18951986), entered Columbia University Teachers College to prepare himself for going to China as an educational missionary. ${ }^{3}$ At Columbia he met his future wife, Mary Katharine Geyer (1897-1986), a graduate of Wesleyan University who was also studying to be a missionary. From 1921 to 1952 Donald's parents were employed by the United Church of Canada as missionaries at the West China Mission in Sichuan province. ${ }^{4}$ They worked in Renshou, Chungking, and Chengdu, and spent a year in the mid-1920s in Shanghai when Sichuan had become too dangerous for foreign missionaries. His parents were associated with a number of mission schools, notably West China Union University, now part of Sichuan University, in Chengdu. Earl had initially planned to assist boys at a Chinese middle school by teaching them basic mechanical skills, including how to develop photographs, as a way of making money to help them pay their tuition. But he actually taught English, education, and Christian moral philosophy at the middle school and university levels. ${ }^{5}$ His highest administrative position was Dean of Studies and Treasurer at West China Union University. Katharine taught English language, composition, and poetry as a part-time teacher in the Foreign Languages Department of West China Union University.

To a contemporary observer, the life of the Willmotts in China is likely to appear as an odd mix of Western imperialism and support for Chinese nationalism, left-wing politics but a comfortable lifestyle. From 1931 until they left China in early 1952 the Willmott family lived on the university campus in Chengdu. Missionaries tended to reside in private homes surrounded by a wall. The Willmotts lived in a three-storey house with two levels of verandas on three sides. Their servants were a gateman who worked as a guard, gardener, and messenger; a cook who was head of the servants and shopped for food; a 


\section{Riggins}

"table boy" who served the food as well as washed and ironed the clothes; a "coolie" who emptied the toilets, cleaned the house, and did odd jobs; and finally an "amah" who was responsible for child care as well as mending and sewing clothes (Willmott, 2013). Before they left Canada, Earl and Katharine actually shipped their sterling silver, English China, and other table items such as fruit napkins to China. But Katharine sometimes wore a fur-lined gown in cold weather that resembled a traditional Chinese scholar's gown (a "changshan") and collected Chinese artifacts (C. Willmott, 2012; E. Willmott, 2013). She was the co-translator and co-editor of Pilgrimage in Poetry to Mount Omei (Phelps and Willmott, 1982). According to Donald, his father helped save West China Union University during the period of ungovernable hyperinflation in the 1940s. As university treasurer, Earl was willing to exchange the Chinese national currency on the black market, unlike his Chinese counterpart. Not all missionaries in Chengdu shared the liberal values of the social gospel. Earl was sometimes accused of being an "un-Christianizer" because some missionaries thought his rejection of the mythological elements of the Bible undermined their work (L.E. Willmott, 1925). ${ }^{6}$

Donald's Chinese name was Yun Da-le. He says that "Da" was originally written by his parents using the character for "big," but as an adult he was embarrassed by his name Cloud Big Happiness. He kept the Chinese sound for "big" but wrote it using the character for the word "attain." In 1941, at the age of 16, Donald assumed he could not really anticipate his future, but he thought his career options were most likely missionary, politician, soldier, or minister. He wrote a very mature essay, "What I want to be," for a class at the Canadian School in Chengdu. His goal in life was to be an objective, intelligent, and useful citizen of the world. He was already sensitive to the tension between objectivity and social activism:

I want to be objective. By this I certainly do not mean "impartial." I think that too many people are wasting their lives because they think they are being objective, when they are really only impartial or neutral. Impartiality leads to inactiveness, whereas objectivity, as I will use this word lies in summing up the truth in a thing with as little prejudice as possible, and then acting on it. I hope I will as often as possible be able to see without the spectacles of prejudice tied around my mind and seeing truth or right, or falsehood, or wrong, act accordingly. (Willmott, 1941) 
After studying as a special student at the University of Nanking when the school had moved upriver to Chengdu because of the Japanese invasion, he taught in 1943-44 at a Chinese middle school near Chengdu connected with Oberlin College in Ohio. At the time the Chinese Communists were not yet openly anti-Christian. For reasons of wartime safety, the secretariat of the YMCA/YWCA was also relocated to Chengdu. These people from the east coast brought a more urgent, radical opposition to the Japanese and the corrupt Nationalists headed by Chiang Kai-shek. At the University of Nanking, Willmott participated in a secret left-wing discussion group along with his father and mother; missionaries Dryden Phelps and J. Spencer Kennard Jr.; and several Chinese people including leaders of the YMCA and YWCA. People passing through town participated for brief periods, the most famous being the historian of science, Joseph Needham.

When his teaching at the middle school was finished (his salary was sometimes in sacks of flour to avoid the rapid inflation of money), he felt that he should contribute to the war effort by working as an English-Chinese translator. He wrote the Canadian attaché in Chungking, the provisional capital, asking to volunteer. The attaché urged him to join the American army because there were no Canadian troops in China, but cautioned that the Americans did not always make effective use of volunteers. Consequently, Willmott worked in 1944-45 for the Office of Strategic Services (OSS), the first national intelligence apparatus in the United States and predecessor of the Central Intelligence Agency. He was a clerk-typist at the OSS headquarters in Chungking doing often highly secret office work. He was given this work while waiting to be assigned to a field location. After a few weeks he was anxious to become more active in the war rather than sit typing on a stool all day. Oliver J. Caldwell (1972) recruited Donald Willmott and Albert Seeley as the first two workers in the "secret, secret service" of the OSS, which was independent of the Chinese Nationalists. Translating daily radio dispatches from Chinese agents in Japanese-held cities became Willmott's next job. Through religious activities and singing in a choir in Chungking, Willmott built up "amazing contacts" with Chinese people (including the educator Tao Xingzhi, who introduced him to the poet Guo Moruo). An Austrian Jew, Ruth Weiss, a political radical and Donald's French teacher in high school, introduced him to people at the Yenan Mission in Chungking, and from there he met others such as Madame Sun Yat-sen.

Thousands of Japanese soldiers and Allied prisoners of war were stranded in China when the hostilities of World War II ended. The Americans attempted 


\section{Riggins}

to prevent the Japanese from surrendering to the Chinese Communists and turning over their equipment and records to them. Willmott's mission, as he understood it, was for him and Laird Ogle to go to a distant city where Japanese soldiers would surrender to them. But the mission evolved after John Birch, Willmott's commanding officer in the OSS, got permission to replace Willmott. ${ }^{8}$ Birch was shot and killed on this mission by a Chinese Communist soldier. A missionary and fluent speaker of Chinese, Birch had established an effective spy network behind Japanese lines. "John Birch died in my shoes" is the way Willmott now likes to tell this story, although he realizes this is not quite true. The American military judge who investigated the death concluded that Birch's belligerent attitude to the Chinese Communists was partly responsible for his death (Walsh, 1975). Had Willmott gone on the mission, he would not have behaved in the same manner. ${ }^{9}$ One of the most famous ultraconservative organizations in America, the John Birch Society, was named in honour of Birch, who was considered to be one of the early martyrs of the Cold War. Needless to say, Birch and Willmott did not agree on politics.

In 2007 Donald Willmott recounted his work as a translator for the OSS in these words:

I was attached to the "Morale Operations" section of the Office of Strategic Services (OSS), which had the job of spreading anti-Japanese propaganda to Chinese people in occupied territories, and ended up at the behind-the-lines base of a network of Chinese spies whose job it was to report on Japanese troop movements and strength. Thus I was not privy to the projects of the "Special Operations" section, from which the OSS got its reputation of being the "Cloak and Dagger" organization. I had only one experience which convinced me that the OSS had no ethical commitment.

I saw and heard enough, however, to continue an interest in the OSS and its successor, the Central Intelligence Agency (CIA), and to read all I could about them ever since. To me, it's a shocking and sordid story, far too little known, or at least, far too little covered by the popular press. I learned, to my surprise, that the first OSS agents were trained in Ajax, near Toronto, by British secret-operations instructors. They were mostly from Harvard and Yale, except for Ilia Tolstoy, grandson of Leo, whom I later met in China. A study of that operation reports the following statement, made by one of the American trainees: "It turned our values upside down and we wondered about 
making a world fit for terrorists." What foresight! In my opinion, the OSS-CIA had a large part in that making, and in shaping events in China. (Willmott, 2007) ${ }^{10}$

\section{DONALD WILLMOTT'S EDUCATION AS A SOCIOLOGIST}

After World War II, Donald Willmott entered the United States through the quota for Chinese immigrants even though he had no Chinese ancestry. ${ }^{11}$ The children of missionaries arriving home as teenagers or young adults sometimes had trouble adjusting. However, this was not the case for Willmott. He was first transferred to the OSS headquarters in Washington, D.C., and worked there for several months before entering university. "I thought I fit right in," Willmott (2013) says. "I immediately had friends all over Washington. I felt like an ordinary person." A very mature 21-year-old, Willmott entered Oberlin College in 1946 and graduated four years later with a B.A. degree in sociology. Veterans entering American universities just after World War II are described by the sociologist David Riesman (1980: 47) as "careerists" who wanted to make up for lost time; they brought self-confidence and a sort of "sober realism" to the classroom. At Oberlin he met the future artist-photographer Elizabeth Herrmann. She says he was "a bit of an oddball" and that one of his charms was that he failed to recognize a lot of little American customs. She gives the example of his riding an old bicycle that no one else at Oberlin would consider using. It broke down repeatedly. Elizabeth commented:

Don grew up in a kind of time warp - being most influenced by people who in a way "hibernated" in China, carrying on much that was part of the society they had originally left. It changed. They didn't much. Their kids did not experience contemporary North American culture, but rather the culture of adults who in a sense lived in the past. ... But I found it interesting to live with! (E. Willmott, 2014)

The adult self-perception of the children of the missionaries in China is that they were more committed to internationalism and social justice and less materialistic than most Canadians (Austin, 1986: 333). This is indeed an accurate depiction of Donald, as it is of Elizabeth.

Donald and his younger brother William are the fourth generation of 


\section{Riggins}

academics among the men in the Willmott family. ${ }^{12}$ (Their great-grandfather and grandfather were professors of dentistry at the University of Toronto.) Donald's adolescent plans to follow in his father's footsteps and become an educational missionary ended when the Chinese Communists closed foreign missions. Instead, Donald and William became social scientists. William, who became a professor of anthropology at the University of Canterbury in Christchurch, New Zealand, wrote that both he and Donald "loved China," but since it was not possible in the 1950s to do research there, they did the next best thing. They studied overseas Chinese societies (W. Willmott, 2012: 14). Donald specialized in studying the Chinese in Indonesia; William studied the Chinese in Cambodia.

In a letter to his parents in June 1948, Willmott credited them for encouraging him to study sociology. ${ }^{13}$ They had "put [him] on the right track." He had initially planned to major in English or history. At first he found the sociology courses at Oberlin to be rather dull. But the college reorganized the department in 1947 and Willmott (1948a) told his parents that he found three new professors to be inspiring. They were Richard R. Myers, a specialist in industrial sociology and social problems; George E. Simpson, an authority on race relations; and J. Milton Yinger, trained in sociology and anthropology and another authority on race relations. Simpson has acquired a sort of mythical status among sociologists because he was the teacher at Temple University in Philadelphia who inspired the young Robert Merton to study sociology. Merton became one of the most influential American sociologists of the twentieth century. Milton Yinger was more influential in Willmott's case. Yinger was closer in age to Donald and Elizabeth, who occasionally served as babysitters for the Yinger family. One characteristic that would have drawn Willmott to Yinger is that both had parents who were Methodist (or United Church) ministers. Oberlin was a liberal institution, the first college in the United States to regularly admit African-American students; the college admitted women as full-time students as early as the 1830s. In letters to his parents, Willmott wrote about politics and religion rather than sociology. He was dismayed by his classmates' attitude to religion. He had hoped to use the vesper services as a forum for discussing world issues but most students were looking for soothing and calming messages. "If Jesus were in Oberlin today, he certainly would not soothe people: he would stir them up, he would denounce, he would urge action, he would antagonize people right and left" (Willmott, 1948b). ${ }^{14}$

In the information Willmott provided Memorial University when he was applying for a position in 1955, he emphasized his experience in research 
methods. He wrote that his most valuable practical experience in research methods had occurred at the University of Michigan at Ann Arbor, where he completed his M.A. degree. At the Center for Group Dynamics there he had participated in a six-person research team directed by Ronald Lippitt, a social psychologist who had studied with celebrated psychologists such as Jean Piaget and Kurt Lewin. Willmott's M.A. thesis was a study of fraternity members who had non-conventional opinions because he could get funding for that topic. At Oberlin and Michigan, Willmott seems to have made a transition from socialism to sociology. Many sociologists of his generation made this transition. Their youthful political opinions, however, left lasting traces. In Willmott's case, it was the somewhat contradictory insistence that a moral vision be combined with scientific sociology.

Cornell University in Ithaca, New York, was a great place for Willmott to continue his interest in China, although "in public there was no real discussion of China at Cornell in those years" (E. Willmott, 2013). The university's Southeast Asia Program was also very attractive. Willmott chose to do all of the work for a Ph.D. in both sociology and Southeast Asian studies, defending his thesis in both departments. The second professor who had the most influence on Willmott was his main supervisor, the political scientist and historian George McTurnan Kahin, who was the founder of the Cornell Modern Indonesia Project and later an influential critic of American policy in Vietnam. Donald and Elizabeth spent May 1954 to August 1955 in Java, Indonesia, where he gathered information for his thesis. At the same time Elizabeth did research for a monograph titled The Role of Women in Indonesia. She was also a great asset in helping Donald interview Indonesian women. Willmott's thesis (1958c) was supported by fellowships from the American and Canadian Social Science Research Councils and the Cornell Modern Indonesia Project.

Willmott asked Robert Merton for advice in writing his thesis. Merton later recommended that the thesis be published by Cornell University Press (Willmott, 1958b, 2013). The Chinese of Semarang: A Changing Minority Community in Indonesia (1960) is a comprehensive study of the assimilation of a classic middleman minority in a non-Western, multicultural setting. One can only speculate about the qualities Merton might have appreciated in the thesis. Merton wrote about ethnic relations when he was young and he frequently evaluated manuscripts for publication. He would surely have liked the fact that Willmott was investigating an important public issue - ethnic conflict - in a dispassionate, objective manner despite his sympathy for Chinese cultures. Merton appreciated sophisticated research methods such as surveys (Crothers, 
1987). The Chinese of Semarang consisted of a careful accumulation of empirical data through wide-ranging sources: a survey of over 1,000 high school students; 50 interviews about the composition of households; participant observation of public events; statistics from government reports; and news stories from newspapers and magazines. The conclusion, although tentative, provided a formal theory of social change that was applicable to any country. Willmott's concern with low-level processes of social change was a good example of middle-range theorizing that led to testable hypotheses. The theory came alive when Willmott used Talcott Parsons's pattern variables to explain the types of values expressed in contacts between ethnic Malays and Indonesians of Chinese ancestry. ${ }^{15}$ Finally, Willmott's thesis was relevant to theories of structural functionalism because he outlined how difficult it was for shared values to unite a pluralistic society. Indonesia was characterized by an exceptional level of cultural diversity due to the competing values of indigenous ethnic groups and the influences of both traditional and modernist China, as well as the lingering influence of the colonial power, the Netherlands. The Chinese of Semarang is Willmott's major publication.

The Willmotts have no document specifically stating that Donald was blacklisted by the American government. However, several incidents suggested this to them. The Committee for a Democratic Far Eastern Policy, based in New York, was officially labelled a Communist front organization. ${ }^{16}$ Board members were automatically blacklisted unless they resigned. Donald sat on the board as a youth representative and never resigned. He felt that liberal organizations were deliberately being destroyed by labelling them as Communist fronts. On principle, he let his name remain. When he was a student at the University of Michigan he once had to report to immigration in Detroit. The immigration official asked him if he would fight for Russia or the United States when war broke out. Surprised by the question, Donald answered that it would be a nuclear war and he would not fight on either side. At Cornell he refused to co-operate with an FBI agent who wanted to interview him. Donald and Elizabeth feared that blacklisting would create problems in defending his Ph.D. thesis. Although this did not happen, crossing the Canadian-American border was a concern for a long time.

There was another dilemma in Willmott's academic career: whether he should concentrate on Far Eastern studies or sociology. Again, being blacklisted complicated things. American sociologists wrote almost exclusively about the United States and cared little about Asia. When Willmott expressed concern about his future in 1957 to one of his thesis advisers, the well-known 
anthropologist and sinologist William G. Skinner replied that many scholars found it difficult to keep up with Far Eastern studies after they had returned home. Skinner (1957) urged Willmott to try to find support somewhere in Canada: "If you can't risk trips to the States, however, I suppose it's only realistic to leave the field as a serious contributor unless you are sustained, as it were, within Canada. Trained sociologists who are FE [Far Eastern] specialists are so rare and so badly needed that it seems almost criminal not to keep up both specialties. I don't envy your dilemma." Willmott found that the possibilities of following his China interests evaporated. ${ }^{17}$

\section{THE WILLMOTTS' SOJOURN IN NEWFOUNDLAND}

In 1951 the Board of Regents at Memorial University asked the retired President of the University of Alberta, Robert Newton, to prepare a report that would serve as a guide for the development of the university. As far as sociology was concerned, Newton's advice was to introduce the discipline as a way of providing a better education for social work majors (Newton, 1952: 46-47). The timing was consistent with the pattern at comparable universities. Carleton, Mt. Allison, Alberta, McMaster, Saskatchewan, and Western Ontario also appointed their first full-time sociologists in the 1950s (Helmes-Hayes and McLaughlin, 2009: 580). Without sufficient numbers to form a department, from 1956, when the first course was offered, to 1965 sociology was housed at Memorial in a Department of Social Studies that consisted of commerce, economics, political science, sociology and anthropology, and, briefly, psychology.

It might seem strange that a Canadian who earned degrees from three different American universities, including his doctorate from an Ivy League school, who married an American, whose mother was American, and who served in the American military would want to teach sociology in Canada in the 1950s. The United States was the international centre for academic sociology; the discipline barely existed in Canada. By the end of the 1950s, only the universities of Alberta, McGill, and Toronto employed more than two full-time sociologists (Helmes-Hayes and McLaughlin, 2009: 580). But in the McCarthy era research even on overseas Chinese was problematic. Elizabeth Willmott writes:

The climate of McCarthyism was strong in the United States. A focus on China, even on the Chinese in southeast Asia, was a particularly difficult specialty for academics with integrity. I recall Professor 


\section{Riggins}

Knight Biggerstaff, a renowned China scholar, getting up to give a public speech at Cornell and reading only from newspapers. I also recall someone I gave as a passport reference shouting gaily across the street to me, "the FBI were asking me about you last week." It was considered normal!

So, we decided to live in Canada. Don developed such severe hay fever at Cornell that we decided we could not consider living in a similar environment. In Canada, that meant not living in Ontario. Newfoundland promised to be allergy free, and so it was! In truth, the advertised position for a sociologist at Memorial University was the only one in Canada that year. There was a hint of one opening in Edmonton, but it was not in place at the time Don had to find something. (E. Willmott, 2013)

In September 1955 Donald and Elizabeth were returning to North America from Indonesia. Donald wrote Memorial University President Raymond Gushue from a ship docked in Suez, Egypt, to ask if he could still apply for the advertised position of assistant professor in sociology. Willmott had heard about the position from David Kirk, a McGill sociology professor who had been a fellow graduate student at Cornell University. ${ }^{18}$ Months after Willmott applied to Memorial, Gordon Rothney, one of the founders of the MUN Department of History, became interested in his application, perhaps because he was a historian of Asia or because he hoped to form an interdisciplinary research team studying Newfoundland. Rothney mentioned the application to Dean of Arts M.O. Morgan, who discovered the university had forgotten to notify Willmott that his application had been successful (Willmott, 2013). Willmott remembers Memorial, despite this inauspicious beginning, as an interesting place to teach, and thinks he was lucky to land the position. Salaries were so low that he was immediately given the position of associate professor so the administration could justify an annual salary of $\$ 5,000$ rather than the normal $\$ 3,000 .{ }^{19}$

Willmott did not visit St. John's before accepting the position; no one at Memorial interviewed him prior to making the offer. He had wrestled over the choice between the universities of Alberta and Memorial by going so far as itemizing their advantages and disadvantages. Memorial's disadvantages included "stagnating" in a Canadian backwater, isolation from the progressive movement, and a greater likelihood of red-baiting. He anticipated religious interference in his sociology courses at Memorial. Its library was poor. He pictured the family attending a "probably oppressive" United Church in St. John's 
rather than a Unitarian Church, which was an option in Edmonton. ${ }^{20} \mathrm{New}$ foundland was further from his parents in Calgary but closer to his in-laws in Washington, D.C.

On the other hand, teaching at Memorial did have advantages Alberta could not match. It would be easier to concentrate on his thesis at Memorial because advanced courses in sociology could not be offered when students had no background in the discipline. Worthwhile research was a real possibility in Newfoundland, although the university put little pressure on faculty to publish. Alberta had higher expectations for research but offered little financial support. He was convinced he had a better chance of giving a course on the Far East at Memorial. Finally, word of mouth (valid in this case) was that the Avalon Peninsula was more attractive than the immediate environment of Edmonton (Willmott, 1956a).

The Willmotts brought to Newfoundland one of the first Volkswagens seen in the province. It attracted attention wherever they went. "We are more or less settled in our house here now," Elizabeth wrote from 20 Hoyles Avenue to Don's brother William and his wife:

... no drapes up, no bookcases or desk so papers and books scattered everywhere. We were happy to find the house waiting for us. The louses - they let us worry to the last minute, didn't notify us about the house at any of the four addresses we gave them. We arrived in St. John's having failed in our efforts to get a hotel reservation and worried by the complete lack of places to rent listed in the newspapers. Then, all smoothed over as we were told about the house. It is really too small for us, but we feel in no position to even think a complaint. We have two bedrooms, living room, and kitchen, and all the rooms are smaller than in our Calgary house. It is a government project, with houses on our side of the street and apartments of a slum clearance type on the other side. Needless to say our side has nothing good to say about the other side. However, the other side in its usual fashion has produced a host of little ones who make good playmates for Kenny. They are wonderfully concerned about the ones a little younger than themselves. I am constantly amazed at the care they take of Ken. But they are always eating sweets, and each mother feeds the whole gang in turn. By lunch time Ken is stuffed. I am really at a loss about it. Just this morning a boy about 6 was playing with Ken. He disappeared out the front door and returned with an ice cream stick for Ken. 


\section{Riggins}

We have had several wonderful picnics so far, though the weather really does leave much to be desired. Our first Sunday we had a lovely picnic on a rocky beach (they all are rocky - rocks the size of your fist) with the blue sea and high cliffs all around. The second Sunday we had a cold drizzly picnic with some faculty on the top of a "mountain" with a view of the sea ahead, and woods and "ponds" (lakes) behind. And the top was covered with luscious blueberries. The next Sunday it really poured, but it was Ken's birthday, so we had a picnic in our car sitting on a pier at the harbor. This past Saturday was lovely, and we went to a little fishing village called Portugal Cove to sit in a cow pasture with a bull rather aggressively eyeing us and Kenny stepping on rocks and what looked like a rock but very unfortunately wasn't. But there was a glorious view of the sea, with waves beating white on the rocks and of the cute little village. (E. Willmott, 1956)

A theme in Elizabeth's recollections of their years at Memorial is that she and Donald were content to enjoy the pleasures of large cities in small doses. This was true for all of the early sociologists and their spouses who were happy in St. John's. "Washington, D.C. museums were a big part of my growing into what I am, as were marble buildings. When traveling in Europe, for example, museums were not a first interest. Landscape and creative people were. I found these in Newfoundland" (E. Willmott, forthcoming). Elizabeth was active in the artistic community in St. John's, where she studied with the Dutch sculptor Hans Melis, whose busts of the founders of Memorial University and Premier Joseph R. Smallwood are still displayed on the university campus.

On 1 October 1956, Willmott wrote William G. Skinner, giving his early impressions of Memorial University and his job:

I find the faculty (only about fifty people) very congenial, on the whole, and there are a few who are already good friends. No one knows anything about sociology, so I have a free hand. I am now trying to get across the idea of scientific methodology to a beginning class of 24. I find "lecturing" very enjoyable - aside from the fact that we are required to wear academic gowns (as are the students, too!). The place is rather stuffy in other respects too, but so far not enough so to bother about. Most of my students are fourth year arts and education students, and fairly mature. So I'm looking forward to a good year with them. 
The research side of my work promises to be fascinating too. Again, no one knows enough about it to interfere very much within broad outlines set by the needs of the Welfare Department. Neither the Deputy Minister nor his assistant, who are my "bosses," has a B.A. and neither has any academic training in social work. Yet both are surprisingly well-informed and broad-minded, and are pleasant to work with. There is still no idea of what I should investigate - except for the vague idea that I should find "the facts" about the "outports"; and for the frustrated feelings of social workers who would like to know why everyone doesn't have good middle class morals and aspirations! (Willmott, 1956b)

William G. Skinner (1956) replied a few weeks later: "The community does sound fascinating if a little fin de siècle."

Donald Willmott had some minor conflicts with influential Catholics at the university despite the fact that Memorial had always been a secular institution. It might help put his experiences in perspective by pointing out that an American Catholic Sociology Association and journal existed in the mid-twentieth century, although they were marginal in the eyes of mainstream sociologists. At issue were the value neutrality advocated by scientifically oriented sociologists and their unwillingness to support the official policies of the Catholic Church, especially on issues related to the family (Blasi and Donahoe, 2002). The quick resolution of disputes over the values taught in the first sociology courses points to a rather high degree of academic freedom at Memorial in the mid-1950s. To quote one of Willmott's personal letters:

Soon after I arrived at Memorial I was summoned to the Department Chair's office. That was Mose Morgan, a political scientist of local origin, who later became Dean and then President. He told me that I was to appear before a meeting of the Board of Governors for questioning. He told me that when the Newfoundland government decided to establish Memorial University, they could only do so with the agreement of the major churches. The Roman Catholic Church agreed only after extracting a promise that the faculty of the Sociology Department and the Philosophy Department would always be Roman Catholic. This was an unwritten "gentleman's agreement" which was already manifest in the one appointment to the Philosophy Department. $^{21}$ 


\section{Riggins}

On hearing this, I indicated some trepidation. Mose said: "Don't worry: just tell the truth."

When I entered the presence of that august body, I noticed that one of the Governors was wearing a clerical collar. It was he who opened the questioning:

"Professor Willmott, to what church do you belong?"

"The United Church."

"I see. And do you believe in birth control?"

"Yes, I do."

At this point, another Governor interjected: "But do you teach birth control?"

"No, I don't see that as my job. On any controversial subject of sociological significance, I elaborate the different points of view and encourage students to come to their own conclusions."

There were a few other questions, but this was the gist of it. I was soon allowed to leave. I later learned that it was at this meeting that the Board decided to confirm appointments on academic grounds, regardless of religious affiliation. I suspected that Mose Morgan, an Anglican Rhodes Scholar and an Oxford graduate, in co-operation with other like-minded university people, had used my case, and perhaps even my original appointment, as a means of affirming academic freedom at Memorial, and of laying to rest the "gentleman's agreement."

It was indeed fascinating, but sometimes a bit trying, to be an "outsider" in Newfoundland during a period of transition from a very traditional society to a more modern one. (Willmott, 1990)

Willmott was able to tell the committee that the type of instruction he did in class was not preaching. ${ }^{22}$ But the committee did not learn that he had written a paper about his personal religious faith as an undergraduate at Oberlin that his professor classified as Christian humanism. Writing to his parents on 5 June 1957, Willmott mentioned a false rumour, circulating, "apparently, from the smoke-filled rooms of the Student Council and the student newspaper to the innermost corners of the girls' toilet" that he was planning to leave Memorial because Catholic powers were interfering with his teaching:

Of course, "where there is smoke, there is fire." I was called before the [university] Senate, in order to satisfy the Catholic powers that be. 
The real issue was what I should teach. And from long talks with Father McGrath and the University librarian (a Catholic) - both on the Senate - I know that they can't approve any type of sociology which isn't specifically Catholic. However, they hadn't a leg to stand on, and hadn't really figured out what position they could take. So the issue came up ostensibly as a question of whether I should include lists of assigned texts and readings in the course descriptions given in the University Calendar!! My explanations of why I couldn't list texts were accepted by the Senate, so the issue was dropped. But not before one Catholic member of the Senate (Classics Professor!) had suggested that perhaps the Calendar should include a description of me and my point of view - so that students would know!! And Father McGrath expounded his views of what sociology should be (i.e. what it is at Catholic University, where he studied), and said that he didn't see how you could teach sociology without social morality. Since the Catholics concerned knew already that I give attention to various points of view on controversial issues (like population) - I had tried to get Father McGrath to speak to the class on Catholic social philosophy even before this issue came up - it is obvious that they are not satisfied merely with having their point of view presented among others. I would not be surprised if I get no Catholic students next year. Anyway, since I didn't have to make the slightest concession, I never dreamed of leaving! (Willmott, 1957e)

In 1957 the single sociology course in the MUN calendar expanded to five, although Willmott was still the only sociologist at the university. The first courses (introductory sociology, community organization, sociological aspects of personality, collective behaviour and social control, cultural anthropology) were the subjects Willmott thought he could credibly teach. Cultural anthropology was on the list because the literature about China and Indonesia that Willmott had read was typically the work of anthropologists. Some of his teachers had taught both sociology and anthropology.

One night a week Willmott taught a course for Public Welfare officers. He complained about this course to Skinner. Students included his boss, the assistant deputy minister. Although Willmott did not make it explicit, he was encountering problems because his students had no background in sociology. He was trying to encourage relativistic thinking among students who had little experience interacting with people of diverse values. 


\section{Riggins}

The most interesting thing is to see how [students in the course] use every conceivable opportunity to "cathart" about their frustrations. Underprivileged people can be so annoying to middle class people! No matter how hard I try to put across the idea of "sub-cultural differences," they can't seem to get away from the idea that their clients are unreasonable, and that their behavior is unintelligible. For instance, they dumped the "false declarations" problem in my lap: "What can be done about the fact that so many of these people make false declarations about their earnings, their rent, their employment, and so on? - in order to get relief supplies." I was a bit annoyed that they should expect a sociologist to deal with such a trivial problem, especially since this same group of people (middle class) / (or at least their brothers and sisters) were year after year systematically claiming $10 \%$ deductions for "contributions" from their taxable incomes - until the Government began to demand receipts! (Willmott, 1957c)

Willmott and social workers from Toronto taught a training conference for welfare officers in the summer of 1957. According to Willmott, the Toronto "experts" confirmed the dominant view within the Department of Public Welfare, thus ignoring or minimizing the rational logic of poor people. "While I was giving sociological explanations of poverty and social problems, the University of Toronto social workers were giving Freudian, individualistic interpretations of poverty. So we were sort of at cross-purposes. It is most comforting to think that the poor themselves are responsible for their poverty" (Willmott, 2007). He hoped that at least some of the trainees got his main idea: psychology cannot explain the political and economic causes of poverty. The psychology of fishing families was influenced by concrete economic, social, geographic, transportational, and fishery-collapse factors that would have to change before psychiatrists were brought in to try out Freud.

Willmott was an enthusiastic public speaker both on and off campus. From an academic perspective these occasions might seem trivial; however, for a public that knew little about sociology, the speeches must have helped establish the legitimacy of sociology, especially when the speaker articulated his message in a non-dogmatic, gentle, and down-to-earth manner. ${ }^{23}$ 


\section{WILLMOTT'S RESEARCH ON NEWFOUNDLAND}

Willmott was engaged in two types of research. One was "scientific" surveys done with the assistance of students. The other was participant observation in which he lived for three to six days in the homes of people in four outports and observed "their problems, lifestyles, beliefs, community relationships, and relationships with the outside world" (Willmott, 2013). He completed a half-dozen reports for the Department of Public Welfare:

\footnotetext{
"Community Relief Incidence in Newfoundland"

"Recipients of Able-bodied Assistance in Newfoundland 1955-58"

"Deserted Wives Dependent upon Social Assistance in Newfoundland"

"Recipients of Able-bodied Assistance in Newfoundland, November 1958"

"Report on the Medical Diagnosis of Social Assistance Clients"

"Informal Report on the Blackhead Road Project"
}

To discuss the most ambitious survey as an example, "Community Relief Incidence in Newfoundland" was undertaken in the summers of 1958 and 1959. It was a comparison of 220 communities ranked in terms of their dependence on public relief. Low dependence meant that less than 10 per cent of the population was receiving public assistance. Willmott's most basic conclusion was that the "relief problem is not primarily one of individual inadequacy. . . . Even the individual aspects of the problem ... can be dealt with at the group or community level" (Willmott, 1959e: 18). On the basis of shared family names Willmott tested the idea that high intermarriage rates characterized more isolated communities. While he found that this was true, he thought it was insignificant because of "regression toward the mean." In other words, patterns of heredity over a period of generations tended to moderate abnormalities. "In some cases, we should also expect a superior endowment to be perpetuated through family inbreeding. There may be quite a few Cleopatras in Newfoundland" (Willmott, 1959: 6). He concluded that dependent communities tended to be socially isolated and smaller, although their populations were growing faster than those of the independent communities. The general educational levels of dependent communities were lower, fewer professionally trained people resided in them, and thus they had fewer people who might become future leaders of voluntary associations. In both cases the illiteracy rates were high. The most recent statistics at the community level were for 


\section{Riggins}

1945. Fifty-seven per cent of those over the age of 30 who resided in dependent communities were illiterate in 1945 compared to 22 per cent in independent communities. A high level of education was likely to be associated with greater self-confidence, more knowledge of the outside world, and greater willingness to face new situations. Communities did have different traditions of seeking employment in distant locations on the basis of the opportunities offered previous generations and the knowledge and social networks these experiences provided. This survey is the kind of fact-finding research that should have been done by government officials. It is based on the methodology of the social sciences, but a collection of data it is not sociology unless it is explicitly related to theory. This is not a criticism of Willmott. He delivered what the Department of Public Welfare apparently wanted.

Willmott spoke about the resettlement of Newfoundland's rural population on a couple of occasions. He argued that government resettlement irrationally facilitated a pattern of natural migration that he called "abortive migration." People did not want to leave home. Consequently, they moved to neighbouring communities that offered no long-term solution to their economic problems. The reluctance of the poorest and least educated families to move was a phenomenon he thought was common in many parts of Canada. Willmott's proposed solution was for modest planned government actions to guide resettlement by deliberately scattering economic opportunities throughout the province, and to help individual families by facilitating the building of low-cost housing and mortgages to buy houses and small plots of land. The practical advice Willmott offered in his various studies and surveys was not controversial, but he did ask for more rationally planned social services. The south coast settlement McCallum, population about 200 in 1957, exemplified the problems he encountered. Its population was expanding due to a high birth rate and the influx of people from nearby smaller communities.

Yet one-third of its families were chronically on relief. Fishing was bringing in less and less income, and jobs in the nearest lumbering area were scarce. There were no road connections to any other place. No telephones. A clergyman held a service there once a month, in the summer time only, and visits from the district doctor were even more rare. The school teacher, a young high school graduate without teacher training, tried to give an education to 63 children in one classroom. No electricity. No amenities. Surely, a clear case of "abortive migration." (Willmott, n.d. 2) 
The theoretical perspective Willmott developed in The Chinese of Semarang could have been tested in Newfoundland. It is sad that Willmott's sojourn in the province was too short to do this. But it would have been the kind of professional research the Department of Public Welfare would probably not have supported. Instead, Willmott embarked on research that might have had more practical value - community leadership in St. John's. This project was never completed although it was his own initiative, not something initiated by Public Welfare. The focus was the amount of overlap in goals and members in voluntary associations, their styles of leadership, the competition for leaders, and the relative contribution of different occupations to leadership (Willmott, n.d. 3). Ronald Lippitt, with whom Willmott had studied at Michigan, was known for research on leadership styles in small groups and applied research related to the principles of deliberate social change. Willmott's thesis also included a brief chapter on leadership. He regretted its brevity but had delayed research on the topic because it was highly political in a multi-ethnic society. He had heard stories about a researcher collecting information on leadership who was forced to leave Indonesia after his research notes were confiscated by the police.

At a 1958 meeting of the St. John's Rotary Club, Willmott talked about his travels on the island and his experiences living in the homes of people in rural communities:

Last summer (my first summer in Newfoundland), I spent a good deal of time traveling around the Island. I visited large towns and small towns, outports and coves - staying from a couple of days to a week or so in each place. I lived in the homes of a taxi driver, a merchant, a lumbercamp foreman, a welfare officer, an old Labrador schooner skipper. I learned to mend nets, and to tie hooks to a trawl line; helped to load fish onto a schooner; got up at the crack of dawn to go with fishermen to their cod nets, salmon nets, and traps; turned carpenter for a day and helped to put up a dining-room ceiling; played with school children and told them stories; showed a young logger how to tune his new guitar, and swapped songs with him; and spent hours and hours sitting with families and neighbors in people's kitchens, or standing on the stages [platforms on stilts for drying cod] with fishermen at work or at leisure. And all the time, of course, I was listening and asking questions. I talked with housewives and clergymen, fishermen and loggers, doctors and teachers, a mill worker and an RCMP sergeant, a municipal councilor and a school principal, a saw-mill owner and the manager of a big store. 


\section{Riggins}

In one settlement of some twenty families, I took an informal census by going from door to door. Of course, some people there thought I was crazy. Others thought I was a "spy." One fellow, I was told, said something like this: "Dis fella comes up and starts talking wit me. 'E asks me all about me work, me family, and everything. I tinks 'e must be a communist!" But for every person who was suspicious towards me, there were half a dozen who were genuinely friendly; for every person who let me turn from their door, there were three who invited me to come in. (Willmott, 1958a)

In 2013 Willmott still fondly recalled a project involving community activism. The work could have been justified to Public Welfare by claiming that socializing with the population gave him access to their private opinions. This was a study of the people living along Blackhead Road in St. John's.

It was an isolated community of welfare recipients across the harbour from St. John's, but connected to the city by a steep, narrow, rocky, winding road. The Welfare Department, like most St. John's residents, considered the people there as incompetent and lazy. But in the course of this study I spent many hours sitting around in their homes, enjoying emerging friendships, and getting an understanding of their problems. I organized a summer recreation program for the children of the community, and found that many of the residents there were happy to provide or build furniture and playground equipment, to take unpaid jobs in the kitchen and building repair, and to do other jobs. The Welfare Department was impressed enough to provide salaries for a playground games director and assistant. I also learned that several of the men had already left for jobs outside Newfoundland, and others were considering it. A number were too old or unhealthy to work. But I did interview a few who were making no effort to get off relief. (Willmott, 2013; see also Willmott, n.d. 4)

In a letter to R.L. Andrews, Deputy Minister of the Department of Public Welfare, Willmott outlined some of the difficulties he had encountered doing research about high levels of public relief in outports. He had difficulty getting public co-operation in welfare-related investigations because, as he said, he could not give interviewees credible answers to their questions about who was paying for his research, what he expected to discover, and the eventual use of 
the results. He had amassed field notes on McCallum and Gillard's Cove, including house-to-house survey data on family composition, occupation, origins, and age and sex distribution. Furthermore, he had collected information on a dozen other communities such as Anderson's Cove, Wild Cove, and Milltown. Gathering information on Gillard's Cove was a problem.

In McCallum I had no trouble in learning people's names, identifying those often on relief, and getting to know them. In Gillard's Cove, however, I met with several difficulties which prevented me from getting an intimate knowledge of the dependency problem. In the first place, my host, a taxi driver, was useless as an "entrée" to the community. Secondly, I encountered much greater suspicion of my intentions than I had in McCallum. . . Because of these reports, and because I had sensed doubt about my role and intentions, I decided to make a point of not asking or learning people's names, and of avoiding subjects that might easily arouse suspicion. (Willmott, 1957b)

Willmott noted in a paper written just before he left MUN, "Possibilities for Social Research in Newfoundland - and Canada," that although Newfoundland was "a sort of Eldorado" for social scientists, no professional sociologist had published any research about the province. Willmott proposed several projects on modernization because Newfoundland appeared to be at an earlier stage of modernization than the rest of North America: "In parts of Newfoundland one might find the 'folk society' which we now understand has never existed in Quebec" (Willmott, 1959b: 2). ${ }^{24}$ Unfortunately, no one attempted his two most interesting proposals. One was a study of the contacts between Newfoundlanders and the transient strangers at the American military base in St. John's. This could have been a fascinating ethnography but it was too late to do it. The base closed in 1960. The second topic was Newfoundlanders' gradual acquisition of a Canadian identity. The Avalon Peninsula in the 1940s had been a centre of opposition to joining Canada. When the Willmotts lived in St. John's:

the "Ode to Newfoundland" and "God Save the Queen" were the only anthems sung at public meetings, and the Union Jack was the only flag flown by anyone except federal government agencies. "Mainlanders" are still generally considered, and often called, "foreigners." Thus Newfoundland would undoubtedly be a good laboratory for the 


\section{Riggins}

researcher interested in processes by which children and adults acquire or lose national identification, and the reasons for qualitative and quantitative variations in such identification. (Willmott, 1959b: 9)

Dean of Arts and Science M.O. Morgan (1992: 38) credited Willmott for proposing the creation of the Institute of Social and Economic Research (ISER). However, Willmott has no recollection of having made the proposal. Perhaps he does not remember because ISER never progressed beyond the stage of informal conversations during his years at Memorial.

\section{RELUCTANT DEPARTURE}

"We met an amazing array of interesting people," Elizabeth has written, emphasizing the cosmopolitan dimensions of the early years of Memorial University:

Brits with theatre experience; a Korean aristocratic physicist and his "ordinary-Canadian-Japanese" wife; Jews who escaped the holocaust; local artists and art students, often from prominent families; another Asia expert hired to teach history; Dr. Glen Bartlett and his wife. Historian Gordon Rothney and his wife were particularly good friends.... We kept in touch with many of these people. The Rothneys went to Winnipeg. Dr. Horace Rosenberg, a Native Newfoundlander, moved to Ottawa. Paddy Drysdale, first in theatre and then in the English Department, edited a Canadian dictionary out of Scarborough. Gordon Goundry, an economics professor, was hired as a provincial economist. He lamented: "If only Joey Smallwood would let me see the contracts before he signs them instead of after!" And he left even before we did. Everyone had a different reason, but many people besides us left. (E. Willmott, forthcoming)

Although most of the Willmotts' friends were outsiders or non-native Newfoundlanders, Donald had friendly relations, long conversations, and frequent meetings with many Newfoundlanders. He was even invited once to Premier Smallwood's home.

On 2 June 1959 President Gushue, writing to one of the candidates seeking to replace Willmott, stated that the university's first sociologist had been "very happy here, as we have been to have him, and he would prefer to stay but is 
leaving for family considerations." In reality, both Donald and Elizabeth (2013) deny that they left St. John's for family reasons. Several factors played a role in their moving to Saskatoon, Saskatchewan, where Donald accepted another position that straddled the academic and policy divide at the Centre for Community Studies. Actually, Willmott had rather low expectations for the Centre but anticipated that the job would help him contribute to debates about public issues. ${ }^{25}$

First, and most important, Willmott (2013) was unhappy about his relationship with the Newfoundland Department of Public Welfare, which "took a lot of [his] time, and ignored and buried [his] reports to them." Most likely his ideas were perceived as too Utopian. ${ }^{26}$ One might think that a left-wing scholar would have anticipated that his work could not have an immediate impact on the public and that he would be constrained by his bureaucratic role. But sociologists educated in the United States just after World War II tended to be optimistic about the possibilities of sociology building public institutions on a rational basis (Sica, 1992: 347). It must also be reiterated that the link with the department was imposed on Willmott by the nature of the position at Memorial University. Elizabeth (2013) suggested that his willingness to work with Welfare officials might have reflected his somewhat naive understanding of North American society. On the other hand, the position probably opened doors that would have been closed to an independent researcher. The fact that no one knew much about sociology at the Newfoundland Department of Public Welfare may not be a significant cause of Willmott's dissatisfaction. The more decisive factor may have been his desire to shape policies because of the enduring influence of the social gospel on his thinking. He did not want to stand on the sidelines.

Since many sociologists have been advisers to government and business organizations, it is easy to generalize about their experiences. In Willmott's era, most American sociologists in governmental posts did not have institutionalized roles that would allow them to determine policy. Neither did Willmott. His research topics were assigned to him. Merton and Lerner (1951: 293; see also Merton, 1957: 207-24) called such people "bureaucratic technicians" and "policy servers." At best, they were appreciated as methodologists but not as advisers. Turner and Turner (1990: 184-88) argue that authority figures, who hold strong opinions on policy, tend to be keen to find "facts" that justify or fine-tune their policies. They are less interested, however, in criticism, speculation about unintended consequences, and innovative ideas unless there is a serious crisis in the organization. Dissatisfaction as an adviser to the government is a common experience among sociologists (Halsey, 2004: 135). To 


\section{Riggins}

quote Irving Louis Horowitz (1964: 22) from his introduction to The New Sociology: "Sociology is not necessarily a tool of policy but functions more ably as a critic of policy. When it becomes otherwise, it turns into a hypocritical extension of special interests - an ideology." It should consequently not be a surprise that powerful civil servants paid little attention to Willmott's research. Perhaps if Willmott had identified consistently with the scientific vision of sociology (that is, engaged in pure research), he might not have cared so much that his ideas were ignored locally. As a scientific sociologist, his targeted readers would have been the international community of social scientists.

In this paper the term "bureaucratic intellectual" refers only to the paid employees of an organization. The implication of the term in the sociological literature is that these people are embedded in government or corporate offices. The bureaucrat is thus part of the establishment. While the actual work of a bureaucratic intellectual resembles that of an independent policy analyst or a paid community consultant, the research occurs in a very different organizational setting. Many years after Willmott left Memorial, local social scientists often published research that was independent policy analysis or community advocacy (Neis, 1992). Willmott did not think this was a practical option for an outsider in 1950s Newfoundland. Perhaps he would have changed his mind had he remained longer in the province. But it is unlikely that any sort of advocacy research would have resulted in research acceptable for publication in peer-reviewed prestigious journals. This would have been a concern, especially in the early years of Willmott's career.

The second reason why the Willmotts left Newfoundland was their reaction to the Newfoundland loggers' strike of 1959. Premier Smallwood prevented the International Woodworkers of America (IWA) from representing provincial loggers although the union was preferred by the majority of the workers (Ladd, 1985). Much of the Newfoundland public, frightened by the possibility of violence, supported Smallwood. The Willmotts saw Smallwood's actions as an attack on free trade unionism. This was a turning point for the Willmotts because they perceived their politics to be at odds with many of the people they knew on campus:

The I.W.A. strike has made us surer than ever that we don't want to stay here. Aside from the Gersons, Rothneys, Rosenbergs, and a few others, virtually everyone we meet is enthusiastically behind the Premier in his union-crushing policy. All the usual Smallwood-haters are putting class above party, and praising the "courage" of the Premier. We 
suddenly realize that the bourgeoisie of Newfoundland is thirty years behind that of most parts of Canada and the U.S. - they do not accept unions nor collective bargaining, and are willing to use any methods against them. When we try to take the other side, however gently, we are considered mad. And almost inevitably the point is made or implied: "You foreigners don't understand Newfoundland and are not committed to its interests." I don't think there is any other part of Canada where it would take as long as it would here for us to be accepted. In fact, I doubt whether we would ever be considered to belong here. It certainly would minimize any political effectiveness we might ever hope to have. As you know, people here still consider Newfoundland as a "country" and the rest of Canada as "foreign" (Willmott, 1959a).

While noting the impact of the loggers strike, Elizabeth put more emphasis in 2013 on the expectation that they would forever be perceived as outsiders:

I recall being shocked when a truck with a loudspeaker drove by our home blasting anti-union slogans. That sort of thing was totally outside of my experience. As well, legislation that made association a crime violated everything I knew about democratic law. But I do not think any of this actually pushed us into believing that we could not live happily in Newfoundland. We were more disturbed by hearing long-time resident Brits referred to as "outsiders." For personal, as well as professional, reasons we both wanted to "belong." This was our first real home - a house with a family. We had been students and wanderers. It was important to "settle down." (E. Willmott, 2013)

She further adds:

Once in Saskatchewan, we became even more aware of the influence of [Donald's] outsider status in Newfoundland. We found that everyone "belonged" in Saskatchewan no matter how recently they had moved there. The "pioneer" was still everyone! (E. Willmott, forthcoming)

In addition, Donald thought the university was "going nowhere" because the construction of the new campus on Elizabeth Avenue was progressing so slowly. It was a common impression. Even the provincial Premier feared for the 


\section{Riggins}

future of Memorial. As well, the Willmotts had associated with Chinese students at every university they attended. Now Donald found himself in a province with few Chinese and no colleagues in sociology. Finally, Willmott was becoming increasingly interested in conducting non-utilitarian research about migration. His "pipe dream" was to conduct an ambitious study of rural-to-urban migration throughout Canada in collaboration with other social scientists. ${ }^{27}$

The time Donald Willmott spent at Memorial University was too brief for him to make a lasting impact on the Department of Sociology. Willmott eventually spent most of his teaching career at the Glendon campus of York University. His students at Glendon included Barbara Neis, who later became one of the MUN sociologists most committed to social activism. When Ian Whitaker, a British-trained social anthropologist and an authority on the Sami in Scandinavia, replaced an American-trained sociologist and an authority on China and Indonesia, there was probably little continuity in the content of the sociology courses at Memorial.

In the final lecture Willmott gave to students at Memorial University in April 1959 he emphasized the point he had made in his teenage essay predicting his future - sociology requires moral commitment and objectivity. "I gave my last lecture yesterday," he wrote his parents, and "spent the whole time talking about the dangers of conformity, and advocating a social scientific attitude towards analyzing problems plus a moral commitment to political and social action!" (Willmott, 1959d: 1). ${ }^{28}$ Thus, as he left Newfoundland in 1959, he embraced much the same "sociological imagination" that the maverick American sociologist, C. Wright Mills, espoused that same year in his classic work of that name (Mills, 1959).

\section{NOTES}

1 I would like to acknowledge the assistance of three anonymous reviewers who helped me think more sociologically. Without the generous assistance of Donald and Elizabeth Willmott this article would not have been possible. I had extensive contacts with Donald in 2007 and with Elizabeth and Donald in 2013 and 2014. This included two visits to Owen Sound, Ontario, long telephone conversations, and many e-mail messages. It seemed pedantic to mention in text citations the specific days these contacts occurred. The times are simply recorded as 2007, 2013, and 2014.

The Left Wing Book Club existed from 1936 to 1948. It was one of the most influential left-wing institutions in the United Kingdom. Discussion groups were affiliated with the club. 
"He [J.B.] is survived by Mrs. Willmott, who is widely known for her work in the cause of missions in connection with the Methodist Church" (anon., 1915a).

The title of this section, "China is always with me," is a statement by Donald Willmott that appears in Canadian Old Photo Project Team (2012: 27). Donald's father, L. (Leslie) Earl Willmott, enlisted in the Canadian armed forces before completing his education as a civil engineer at the School of Practical Science at the University of Toronto, but was given a degree, like many others, because of his war service. During World War I, Earl served as an engineer at the Battle of Vimy Ridge before becoming an instructor in aviation for the Royal Air Force. Following the war, he worked briefly on the construction of a northern Ontario railway.

4 Missionaries were granted long furloughs depending on the length of time they had been employed and on social conditions in their host country. The Willmott family spent two extended periods in North America during these 31 years.

5 Earl Willmott's official positions were Principal of the Sichuan Renshou County Huaying Middle School (Renshou No. 1 Middle School today), Deputy Principal of Chongqing Men's High School and Chengdu Union Middle School, and Dean of Studies and Treasurer of West China Union University. As an unofficial athletic instructor in Renshou, Earl was influential in introducing basketball.

6 In Saving China: Canadian Missionaries in the Middle Kingdom 1888-1959, Alvyn J. Austin (1986: 314) identified a group of eight missionaries out of about 50 who had left-wing sympathies in the late 1940s. Earl Willmott was part of this small group. For the general Canadian population the best-known member was James Endicott, a friend of the Willmotts.

Earl and Katharine were disciples of Henry Burton Sharman. They appreciated his method of Bible study, which was to excerpt passages from the Synoptic Gospels (Matthew, Mark, and Luke) illustrating Jesus as a teacher. Almost all of the miraculous elements of the New Testament were omitted in Sharman's selections. Sharman wanted readers to respond directly to the selections as if they were encountering them for the first time. The lessons were organized as a Socratic dialogue (Sharman, 1935; Group of Friends, 1959). Earl Willmott and Dryden Phelps created summer seminars of Bible study near scenic Mount Omei, one of the four sacred Buddhist mountains of China, modelled after Sharman's summer seminars in the wilderness of Algonquin Park in Ontario. Earl and Katharine, along with four other missionaries, published a ChineseEnglish translation of a Sharman text, Jesus: A Life Taken from the Records of Matthew, Mark, and Luke (L.E. Willmott et al., 1936). Two factions developed in the Sharman group with different opinions about the main emphasis in the teachings of Jesus. One emphasized personal salvation. The other emphasized social activism. Earl identified with the latter position, as would be expected given his identity with the social gospel. Earl and Katharine Willmott left the Sharman group before it evolved in California into a cult or sect, depending on one's perspective, called Creative Initiative (Gelber and Cook, 1990).

7 Missionaries needed a Chinese name. Donald's father wanted something genuinely Chinese, something that had depth to it. The name he chose was Yun Cong-long 


\section{Riggins}

(Cloud Follows Dragon). The name comes from the popular Chinese saying "Clouds follow the dragon, winds follow the tiger." The dragon is assumed to be a benevolent creature in China and represents the yang path (the active path) to change in the $I$ Ching. Cloud thus became the family name. Katharine was known as Yun Rui-xiang (Cloud Auspicious).

8 There is more than one version of the events surrounding the death of John Birch, although all agree that he was killed by a Chinese Communist soldier. We will probably never know the full story. The account in Maochun Yu's book, OSS in China: Prelude to Cold War, is that a small group of Americans, Chinese Nationalists, and Koreans were given the mission of gathering information about Japanese airfields in nearby cities that could be used in the liberation of prisoners of war. They would gather whatever intelligence they could along the way (Yu, 1996: 235-41).

9 Elizabeth Willmott (2013) writing to Stephen Riggins: "Don liked John Birch as a person. He did a wonderful job at intelligence using his Christian network as 'eyes and ears' in the Japanese-held areas. He knew the language well. These people were amazingly loyal to him. They were all what we would call 'fundamentalists.' Birch had been associated with a fundamentalist Bible College in the US before going to China. Why is their Christian identity so often left out of the story?

"Don told me before the fatal trip came up that Birch talked about the 'real war' that would occur after the end of the war with Japan. As I understand it, he saw that upcoming war as a kind of final war if not an actual Armageddon."

10 In 2005, Donald was among the 6,000 people invited to Beijing by the Chinese government to attend an extravagant three-day celebration (centred in the Great Hall of the People) commemorating the sixtieth anniversary of the end of the Sino-Japanese war. The Willmotts did visit China for the anniversary. See Sun (2005) and Wang (2008).

11 Donald Willmott (2013) writing to Stephen Riggins: "Although my father was born in Canada and my mother in the States, I was technically a British subject - as were all Canadians at the time. Years later, when Canadian citizenship was established by law, 'Canadians' living outside the country were given four years to register for citizenship. I did not hear about this law, because I was studying at Oberlin College, the American sponsor of the high school in China where I had been teaching English for a year (and was labeled 'wa-wa jiao yuan', kid teacher, behind my back). Thus, in 1954, I was refused a Canadian passport, and referred to the British consulate. There I was informed that I was not entitled to a British passport because I had never lived in the United Kingdom. However, the Consul took pity on me, and 'fudged' a passport listing me as a citizen of Malta."

12 Donald Willmott's great-grandfather J.B. (James Branston) was Dean of the Royal College of Dental Surgeons of Ontario, founder of the school of dentistry at the University of Toronto, and in obituaries is identified as the "father of professional dentistry in Ontario" (anon., 1915a; anon., 1915b). Walter Willmott, Donald's grandfather, also taught dentistry at the University of Toronto.

13 In the letter Willmott actually thanks his mother for encouraging him to study sociology. But both Donald and Elizabeth think this is unrealistic because she had wanted him to 


\section{Memorial University's First Sociologist 77}

study English or history. Their perception is that Donald's decision to study sociology was more consistent with his father's wishes.

14 Not all of Donald's relatives were happy about his politics. In an undated letter to his maternal grandmother he wrote: "I assume that you believe in America's heritage of freedom and democracy. You seem to assume that I do not. 'Don't forget that you are a guest here - and be very thankful for the freedom you enjoy'. And yet you seem to condone a system under which you feel compelled to advise me to hide my views, remove literature from my room, and burn a letter - just as if I were in Nazi Germany! I cannot figure out quite what you do think. Do I have the freedom to say what I honestly believe, here in America, or is that freedom denied me? Should I work for peace in the way I sincerely believe is best, or is there already a 'party line' in America which everyone must follow?" (Willmott, n.d. 6).

15 Talcott Parsons's pattern variables are supposed to exhaust all of the possible value orientations people can express in any situation in any society. They can be used as well to describe the value orientations required by institutions and roles: affectivity or affective neutrality, collectivity or self, particularism or universalism, diffuseness or specificity, ascription or achievement, and expressive or instrumental.

16 <en.wikipedia.org/wiki/Communist_front>. Accessed 2 Dec. 2013.

17 Elizabeth Willmott (2014) writing to Stephen Riggins: "Don moved to the University of Toronto at half the salary he received in Saskatoon with the hope that Asian studies would expand beyond discussions of ancient vases! It did, but not until after he moved to Glendon College. There he became part of the University of Toronto-York University Joint East Asian Program, where he taught some courses on China at the York campus."

18 In Canada, Willmott could not escape the shadow of American politics. He was offered the opportunity of teaching a sociology course at the American base in St. John's but turned it down because it required a security check. MUN administrators had encouraged teaching at the military base. Thus Willmott felt obliged to explain to President Gushue that he had been blacklisted in the US. In 1959, when Willmott accepted a research position at the Centre for Community Studies in Saskatoon, he again felt obliged to explain his American status because he was officially an employee of the Saskatchewan government. Apparently, the relevant authorities in Saskatchewan said they would just toss his letter in the wastebasket.

19 MUN President Raymond Gushue noted the introduction of sociology in his President's Report: "The study of sociology was introduced this year and the one course given, an introduction to sociology, was deliberately treated in a tentative and experimental fashion. ... Though tentative, the course did not by any means lack intrinsic value and the students who completed it not only achieved a wholesome appreciation of sociology as an academic discipline but got useful training in intelligent reading and independent thinking" (Gushue, 1957: 12-13).

20 The Willmotts attended the Gower Street United Church because it was the church the Rothneys attended. But the Willmotts did not become official members because they anticipated that the minister would not approve of their religious beliefs. 


\section{Riggins}

21 Norman J.P. Brown, who is now 91 years old, was the first philosopher at Memorial University. An amateur musician, he played the organ and sang for weekday masses at the Roman Catholic Basilica in St. John's. See Brown (forthcoming).

22 The textbook Willmott used for the introductory course was Arnold W. Green's Sociology: An Analysis of Life in Modern Society (New York: McGraw-Hill, 1952).

23 In his letters to family members, Willmott mentions that he was on the advisory board of the Student Christian Movement (SCM); spoke about religious intermarriage at a SCM supper; ran a study group on race relations in South Africa for the SCM; spoke about "music and morals in modern society" at the YMCA; served on a public panel about vandalism (the Deputy Minister of Education attended); spoke about "social factors in food tastes" for the Home Economics Association; served on a Humanities Association panel on the decline of the outports; gave an interview introducing sociology as an academic discipline for a local religious radio station; served on a University Women's Club panel about "how the home, the church, the school and the community can contribute to a person's education"; made a speech at a dinner in Grand Falls of the Community Welfare Council; helped out for a week with the Maritime Conference on Social Work; participated in the local branch of the Canadian Institute of International Relations; served on the MUN faculty "watchdog committee" monitoring the activities of the university Senate; held the office of secretary for the committee that administered the Newfoundland Archives at Memorial; was appointed to the university's committee on graduate studies; served on the province's "sociology curriculum committee" for Newfoundland high schools; and did "odd jobs" for the provincial department of adult education and its $4-\mathrm{H}$ movement. Finally, it should be noted that he was a supporter of cultural nationalism in Canada before it became a fad (Willmott, 1957d). The Willmotts occasionally invited students over to their home for "folk-song evenings" that included everyone singing Newfoundland songs.

24 The American anthropologist Horace Miner stated in his 1939 book, St. Denis: A French Canadian Parish, that rural Quebec was a folk society. Willmott's statement that a folk society never existed in Quebec is a reference to the ideas of Philippe Garigue in Etudes sur le Canada français, 5-28. Garigue criticized Miner and claimed that the culture of rural Quebec reflected the culture of cities in Quebec. For that reason a specifically rural culture never existed in the province. Later writers, however, did not find Garigue's position to be very convincing. See Richard Handler, Nationalism and the Politics of Culture in Quebec, 52-80.

25 "As for the Centre for Community Studies, I would not expect that my job there to be of great significance. But I do think that it would give me time and opportunity to read, observe, and think a lot about social and political realities in Canada, and thus be a better background than an academic job for some later contribution at the policy \& planning level" (Willmott, 1959c).

26 Here is perhaps the best evidence that Willmott's ideas might have been perceived in the Department of Public Welfare as too Utopian. Willmott wrote on 12 August 1957 to R.L. Andrews, Deputy Minister, Department of Public Welfare, St. John's: 
"I have carefully considered your letter of March 11, 1957. Its general implication, I believe, is that research should be geared to the problem of how Newfoundland's abnormally high rates of dependency on government assistance can be cut. I consider this a reasonable and realistic aim. With the exception of able-bodied assistance, however (and 'sick relief' where it is substantially the same thing), I have come to the conclusion that while research might help to predict future rates, it would do little to show ways to reduce those rates.

"So far as I can see, then, the major area in which I can do research that might be of utility to the Department is that of able-bodied assistance. And, I confess, I am a bit discouraged even about this problem, because, after a great deal of thought, I cannot foresee any possible 'solutions' which might arise out of my research which would not call for increased personnel or unusual expenses to an extent which the Department is not likely to be able to consider. Nevertheless, I am very much interested in this question myself, and willing to tackle it" (Willmott, 1957b).

27 Donald Willmott (2013) writing to Stephen Riggins: "The ranking of universities was not an important factor in my choice of potential jobs. When we left Memorial ... I had become interested in 'community development.' At the University of Saskatchewan a 'Centre for Community Studies' was developing, with the idea that if small towns established 'community councils' consisting of a cross-section of citizens, they could identify and help to establish all kinds of local programs for the benefit of all groups. We thought of it as a promising way of boosting the local economy and ameliorating poverty. I would be involved in the research aiming to assess local programs, but would also be teaching courses at the university. This represents a change in my idea of what kind of research I wanted to do: that is, from 'scientific' polling which showed statistically the true current situation, to careful research which leads to progress in democratic relations, e.g., from showing the interesting variety of backgrounds and ideas in fraternities, to providing the basis for community action in the citizen-based 'community councils' that the Centre for Community Relations set up.

"It sounded great, but as it turned out the centre was only nominally attached to the University of Saskatchewan, and the university professors blocked centre sociologists from teaching there. I published two major reports on our community councils in three places, and a journal article or two. When Tommy Douglas [left] the premiership of Saskatchewan [in 1961], the Centre for Community Studies [soon thereafter] lost its financing and was ... closed down. By this time I had lost my fear of hay fever in Toronto, so I taught at the University of Toronto for a number of years, and then moved to Glendon College, a more beautiful and progressive institution vaguely attached to York University."

Arthur K. Davis (1990: 294-314) has written a detailed history of the collapse of the Centre for Community Studies.

28 In 2013 Willmott still advocated this position. He wrote to Stephen Riggins: "I believe that in order to be an effective activist one must have the best possible understanding of society and its issues. [Otherwise], you'll mess up what you want to do. I considered my job in teaching was to give people the correct understanding of the issues. Sharman 


\section{Riggins}

was my ideal. You do not always state your own position. This means that in talking about politics you deliberately identify the good things and the bad things which different people and different parties do. For example, there are many things which Premier Smallwood did that were good for society, certainly when we first arrived in Newfoundland. You have to talk about the good points of the opposition as well as the weak points of your own party."

\section{REFERENCES}

Anon. 1915a. "Dr. Willmott Dead: Dental College Dean, Father of Professional Dentistry in Ontario," The Globe, 15 June.

Anon. 1915b. "The Late Dr. J.B. Willmott," Christian Guardian, 30 June.

Anon. 1941. "Unique Dental Career," University of Toronto Monthly, 42 (Oct.): 17.

Austin, Alvyn J. 1986. Saving China: Canadian Missionaries in the Middle Kingdom 18881959. Toronto: University of Toronto Press.

Blasi, Anthony J., and Bernard F. Donahoe. 2002. A History of Sociological Research and Teaching at Catholic Notre Dame University, Indiana. Lewiston, NY: Edwin Mellen Press.

Brown, Norman J.P. Forthcoming. "Philosophy, Music, and Public Broadcasting: My Life in Newfoundland," in Roberta Buchanan and Stephen Harold Riggins, eds., "Personal Memoirs of Memorial University, 1950-1990" (working title).

Caldwell, Oliver J. 1972. A Secret War: Americans in China, 1944-1945. Carbondale, Ill.: Southern Illinois University Press.

Canadian Old Photo Project Team. 2012. Chengdu, My Home. Chengdu: Sichuan Literature and Art Publishing House, Sichuan Publishing Company.

Crothers, Charles. 1987. Robert K. Merton. London: Tavistock.

Davis, Arthur K. 1990. Farewell to Earth: The Collected Writings of Arthur K. Davis, vol. 1. Adamant, Vt.: Adamant Press.

Garigue, Philippe. 1958. Etudes sur le Canada français. Montréal: Presses de l'Université de Montréal.

Gelber, Steven M., and Martin L. Cook. 1990. Saving the Earth: The History of a Middle-Class Millenarian Movement. Berkeley: University of California Press.

Group of Friends. 1959. This One Thing: A Tribute to Henry Burton Sharman B.S.A. (Toronto); PhD (Chicago) 1865-1953. Toronto: Student Christian Movement of Canada.

Gushue, Raymond. 1957. President's Report 1956-57. St. John's: Memorial University of Newfoundland.

Halsey, A.H. 2004. A History of Sociology in Britain. Oxford: Oxford University Press.

Handler, Richard. 1988. Nationalism and the Politics of Culture in Quebec. Madison: University of Wisconsin Press.

Helmes-Hayes, Rick, and Neil McLaughlin. 2009. "Public Sociology in Canada: Debates, Research, and Historical Context," Canadian Journal of Sociology 34, 3: 573-600. 
Horowitz, Irving Louis, ed. 1964. The New Sociology: Essays in Social Science and Social Theory in Honor of C. Wright Mills. New York: Oxford University Press.

Ladd, H. Landon. 1985. “The Newfoundland Loggers' Strike of 1959," in W.J.C. Cherwinski and Gregory S. Kealey, eds., Lectures in Canadian Labour and Working-Class History. Toronto: Committee on Canadian Labour History and New Hogtown Press, 148-64.

Merton, Robert K. 1957. Social Theory and Social Structure. Glencoe, Ill.: Free Press. - and Daniel Lerner. 1951. "Social Scientists and Research Policy," in Daniel Lerner and Harold D. Lasswell, eds., The Policy Sciences. Stanford, Calif.: Stanford University Press, 282-307.

Mills, C. Wright. 1959. The Sociological Imagination. New York: Oxford University Press.

Miner, Horace. 1939. St. Denis: A French Canadian Parish. Chicago: University of Chicago Press. Morgan, M.O. 1992. "Remarks on the 30th Anniversary of ISER," ISER Research and Policy Papers no. 15 (Nov.): 33-41.

Neis, Barbara. 1992. "The Uneasy Marriage of Academic and Policy Work: Reflections on the Newfoundland and Labrador Experience," in William K. Carroll et al., eds., Fragile Truths: Twenty-Five Years of Sociology and Anthropology in Canada. Ottawa: Carleton University Press, 321-37.

Newton, Robert. 1952. Report on his Survey of the Memorial University of Newfoundland made at the Request of the Board of Regents of the University in March 1951. St. John's: Memorial University of Newfoundland.

Phelps, Dryden, and Mary Katharine Willmott, eds. and trans. 1982. Pilgrimage in Poetry to Mount Omei. Hong Kong: Cosmos Books.

Riesman, David. 1980. On Higher Education: The Academic Enterprise in an Era of Rising Student Consumerism. San Francisco: Jossey-Bass.

Sharman, Henry Burton. 1935. Jesus as Teacher. New York: Harper \& Brothers.

Sica, Alan. 1992. "The Rhetoric of Sociology and Its Audience," in Terence C. Halliday and Morris Janowitz, eds., Sociology and Its Publics: The Forms and Fates of Disciplinary Organization. Chicago: University of Chicago Press, 347-72.

Skinner, William G. 1956. Letter to Donald Willmott, 18 Nov. William G. Skinner Collection, Cornell University Library, Division of Rare Books and Manuscript Collections.

_-_. 1957. Letter to Donald Willmott, 19 May. William G. Skinner Collection, Cornell University Library, Division of Rare Books and Manuscript Collections.

Sun, Shangwu. 2005. "Militarism Condemned by War Veterans," China Daily, Sept., 2.

Turner, Stephen Park, and Jonathan H. Turner. 1990. The Impossible Science: An Institutional Analysis of American Sociology. Newbury Park, Calif.: Sage.

Walsh, James P. 1975. "The Death of John Birch - Documented," Wisconsin Magazine of History 58, 3: 209-18.

Wang, Ru. 2008. "Where the Heart Is," China Daily, 8 Apr., 18.

Willmott, Cory. 2012. "The Paradox of Gender among West China Missionary Collectors, 1920-1950," Social Sciences and Missions 25, 129-65.

Willmott, Donald Earl. n.d. 1. Curriculum Vitae, apparently 1955. Memorial University Archives. 


\section{Riggins}

- - - n.d. 2. "Discussion of 'Resettlement in Rural Newfoundland' by Ian Whitaker." Willmott family papers, Owen Sound, Ont.

- - - n.d. 3. Letter to Harold Luscome, St. John's. Willmott family papers, Owen Sound, Ont.

- - - n.d. 4. "Informal Report on the Blackhead Road Project." Willmott family papers, Owen Sound, Ont.

—_- n.d. 5. “A Medieval Modern Major General.” Willmott family papers, Owen Sound, Ont.

- - . n.d. 6. Letter to his maternal grandmother. Willmott family papers, Owen Sound, Ont.

_-_. 1941. "What I Want to Be," Dec. Willmott family papers, Owen Sound, Ont.

- - . 1948a. Letter to his father, 1 June. Willmott family papers, Owen Sound, Ont.

- - - 1948b. Letter to his father, 19 Dec. Willmott family papers, Owen Sound, Ont.

-_- 1955a. Letter to MUN President Raymond Gushue, 4 Sept. Memorial University Archives.

- - - 1955b. Letter to MUN President Raymond Gushue, 23 Dec. Memorial University Archives.

_- - 1956a. "Trying to Decide on First Job." Willmott family papers, Owen Sound, Ont.

-__. 1956b. Letter to William G. Skinner, 1 Oct. William G. Skinner Collection, Cornell University Library, Division of Rare Books and Manuscript Collections.

_-_. 1957a. "Memorandum on Social Research." Addressed to Mr. Andrews, Deputy Minister, and Mr. Godfrey, Assistant Deputy Minister, Department of Public Welfare, 11 Mar. Willmott family papers, Owen Sound, Ont.

- - . 1957b. Memorandum to R.L. Andrews, Deputy Minister, Department of Public Welfare, St. John's, 12 Aug. Willmott family papers, Owen Sound, Ont.

-_-. 1957c. Letter to William G. Skinner, 7 Mar. William G. Skinner Collection, Cornell University Library, Division of Rare Books and Manuscript Collections.

- - . 1957d. Letter to his parents, 11 Apr. Willmott family papers, Owen Sound, Ont.

- - - 1957e. Letter to his parents, 5 June. Willmott family papers, Owen Sound, Ont.

-_- 1957f. Letter to an unknown recipient, 14 Sept. Willmott family papers, Owen Sound, Ont.

- - . 1957g. Letter to his parents, 23 Sept. Willmott family papers, Owen Sound, Ont.

- - . 1957h. Excerpt from a letter to an unknown recipient, 24 Sept. Willmott family papers, Owen Sound, Ont.

- _- 1958a. "A Sociologist Looks at Newfoundland," speech given to the St. John's Rotary Club, Jan. Willmott family papers, Owen Sound, Ont.

_- - 1958b. Letter to "dear relatives all," 16 Nov. Willmott family papers, Owen Sound, Ont.

- - 1958c. "Sociocultural Change among the Chinese of Semarang, Indonesia," Ph.D. thesis, Cornell University.

- - . 1959a. Letter written to an unknown recipient, Jan. Willmott family papers, Owen Sound, Ont.

-__. 1959b. "Possibilities for Social Research in Newfoundland — and Canada," informal comments prepared for discussion at the June 5th meeting of the Canadian Sociology and Anthropology Association. Willmott family papers, Owen Sound, Ont. 
- - . 1959c. Letter to his mother, 7 Mar. Willmott family papers, Owen Sound, Ont.

- - . 1959d. Letter to his parents, 18 Apr. Willmott family papers, Owen Sound, Ont.

-_-. 1959e. "Community Relief Incidence in Newfoundland," Report to the Newfoundland Department of Public Welfare, St. John's.

-_- 1960. The Chinese of Semarang: A Changing Minority Community in Indonesia. Ithaca, NY: Cornell University Press.

-_- 1961. The National Status of the Chinese in Indonesia 1900-1958. Ithaca, NY: Monograph Series, Modern Indonesia Project, Department of Far Eastern Studies, Cornell University.

- - - 1990. Letter to Barbara Neis, 14 July. Willmott family papers, Owen Sound, Ont.

- - 2007. Telephone interview conducted by Stephen Riggins, 19 July; e-mail messages to Stephen Riggins, 16 Aug., 1 Oct.

- - - and Elizabeth Willmott. 2013, 2014. Interviews in their Owen Sound, Ont., home by Stephen Riggins, 24-25 June and 27-29 July; Telephone interview by Stephen Riggins, 8 July; e-mail messages to Stephen Riggins in 2013: 16, 24 Mar., 10, 28 Apr., 8 May, 22 June, 7, 16, 17, 19 July, 13, 25, 28 Aug., 8, 17, 21, 26 Sept., 3 Oct., 16 Nov.; e-mail messages to Stephen Riggins in 2014: 4, 5 Jan.

Willmott, Elizabeth. 1956. Letter to William and Margaret Willmott, 2 Oct. Willmott family papers, Owen Sound, Ont.

- - . 1958. Letter to Katharine and Earl Willmott, Easter. Willmott family papers, Owen Sound, Ont.

- - - Forthcoming. "A Faculty Wife in the 1950s," in Roberta Buchanan and Stephen Harold Riggins, eds., "Personal Memoirs of Memorial University, 1950-1990” (working title).

Willmott, James Branston. n.d. Biographical File, University of Toronto Archives.

Willmott, L. Earl. n.d. Biographical File, University of Toronto Archives.

_-_ (attributed to). 1925. "A Conversation," West China Missionary News (June): 26-30.

-_- 1953. "The Church in the New China," United Church Observer Part I (1 May): 11, 38; Part II (15 May): 18, 24.

_-_, Mary Katharine Willmott, Dryden Linsley Phelps, Margaret Hallenbeck Phelps, Lewis Calvin Walmsley, and Constance Kilborn Walmsley. 1936. Jesus: A Life Taken from the Records of Matthew, Mark, and Luke. Chengdu: Canadian Mission Press.

Willmott, Mary Katharine. 1938. “Apologia," West China Missionary News 40, 6 (June): 202-03. Willmott, William E. 2012. "Research in Cambodia, Half a Century Ago: An Address to the Thailand, Laos, Cambodia Studies Group," Cross-Currents E-Journal no. 4 (Sept.). Accessed 7 January 2014. At: <cross-currents.berkeley.edu/e-journal/issue-4>.

Yu, Maochun. 1996. OSS in China: Prelude to Cold War. New Haven: Yale University Press. 